\title{
To Be an Islamic Female Leader: The Education System at the Madrasah Muallimaat Muhammadiyah
}

\author{
$1^{\text {st }}$ Mutiah Amini* \\ Department of History, \\ Faculty of Cultural Sciences, Universitas Gadjah Mada \\ Yogyakarta, Indonesia \\ mutiah.a@ugm.ac.id
}

\begin{abstract}
This paper aims to discuss the education system which was developed by the Muhammadiyah in Yogyakarta to encourage the young women to be a prospective Islamic leader. This madrasah was established in 1932, but the pioneer dated back in 1918. Historically, this madrasah was developed to teach women and to facilitate the needs of Islamic female leaders in Indonesia, which was increasing in the 1920s and 1930s. This condition occurred as the colonial education systems thriving, but the colonial government did not prepare the teachers, especially the Muslim teachers. To produce the best alumni who were ready to be deployed as the female Islamic leader, the student who studied in this madrasah were confined in a dormitory for a
\end{abstract}

\section{INTRODUCTION}

Islamic education recognizes the existence of pesantren and madrasah. A pesantren is a formal education with an individualized system developed by a Kyai, with a curriculum that is strictly determined by the figure of a Kyai himself. Whereas, a madrasah is a formal religious education conveyed in a classical way with a curriculum developed that no longer rely on a Kyai but an existing education system. Traditionally, the pesantren system is conducted in various pondok, a localized term for a pesantren since the colonial time. Normally, the selected students from a renowned pesantren would then continue to a higher level of religious education in Mecca. Afterward, they would establish their own pesantrens in other places. Some of them would generate a pattern of networking among the Kyais of those pesantrens [1]. period of 6 years. In this case, after they graduated from this madrasah, they could contribute actively as a leader in society, becoming excellent teachers and ideal housewives. Therefore, there were plenty of programs designed for them during their study. They covered all general education, religious, teaching, and household knowledge. Through this focus and continuous curriculum with intensive supervision, this madrasah still exists until this present-day. The historical method is utilized to conduct research for this paper by examining documents, oral and visual sources that result in the production of historical facts.

Keywords-Education Systems, Islamic Female Leader, Muallimaat, Muhammadiyah, Yogyakarta

A different condition occurs in a madrasah, in which it is basically a blended educational system between a pesantren and modern educational system. Because of that, the curriculum and level of education in a madrasah resembling the modern system developed by the colonial administration in the $20^{\text {th }}$ century. Muallimaat Muhammadiyah is one of the Madrasah educational systems that thrived in Indonesia since the 1920s. The madrasah was established to answer a variety of problems concerning education in Indonesia. Numerous formal educational institutions in the elementary level established by the colonial administration were incongruent with the redundancy of teachers. Thus, it forced K.H. Ahmad Dahlan, the founder of Muallimaat, to establish an educational institution for teacher entrants (kweekschool). 
Madrasah MuallimaatMuhammadiyah is the only madrasah which was pioneered and entirely supervised by the Muhammadiyah organization. This organization was founded by K.H. Ahmad Dahlan in 1912 [2]. Education is the most significant foundation when it was established. This is what differs the Muhammadiyah with their religious organization counterparts which also flourished in the early $20^{\text {th }}$ century. The consistency of education keeps being maintained in this organization, because of the very reason for education, this organization historically carved its foundation. Before the Muhammadiyah as an independent organization, K.H. Ahmad Dahlan as its founder had developed elementary education. After he developed the elementary education, K.H. Ahmad Dahlan realized the importance to establish a school for teachers to educate future Islamic teachers. It inspired the birth of Madrasah Muallimaat which was initially established along with Pondok Muhammadiyah that had madrasah for both male and female, Madrasah Muallimien and Madrasah Muallimaat, respectively on 1 January 1932. The initial students of the Madrasah Muallimaat were 20 people, coming from Yogyakarta, Cilacap, Banjarnegara, Temanggung, and Purwokerto. They were the daughters of local Muhammadiyah figures in their respective places of origin[3].

Several previous studies by researchers such as bachelor thesis by SalisMustaani[4] and master thesis by Rita Hayati [5] examined general explanation of studying procession at the Madrasah Muallimaat without providing occurrence of the historical process and how chronological curricula there forged female Islamic leaders consistently. Therefore, it is significant to emphasize this paper in its historical chronology.

Based on that emphasis, this article will further discuss the consistent strategy launched by the Madrasah Muallimaat Muhammadiyah since its emergence in 1932 until today, to its current state amidst the growth of education in Indonesia. In contrast with other madrasah in Indonesia, Madrasah Muallimaat has unique characteristics such as the consistency of prospective students, by combining feminine and leadership values in their education curriculum. Hence, the noteworthy discussion lies in the education system of the Madrasah Muallimaat Muhammadiyah.

\section{METHOD}

This paper limits its focus to an institution owned by Muhammadiyah to observe the uniqueness of its education system. Muhammadiyah is a centralized organization in Yogyakarta, unlike other socio-political organizations in Indonesia that are often located in Jakarta. In Yogyakarta, Madrasah Muallimaat has maintained its position for decades and remained until today. Thus, the spatial scope of this paper only covers one madrasah, namely the Madrasah Muallimaat Muhammadiyah in Yogyakarta which was established since 1919 and continues operating until now. The temporal limitation in this paper starts from the time the madrasah first began, which was then called the Muhammadiyah School of Teaching, until now along with other the teacher's education system as competitors. However, compared to other Islamic educational institutions, Madrasah Muallimaat Muhammadiyah has what it takes to survive due to the timeless slogan of this madrasah, which is to serve as a madrasah to educate Muslim women to be a leader.

This research is conducted through a historical research method by utilizing a variety of data available, namely the ones that are either written, oral, and visual [6]. As the only madrasah owned by the Muhammadiyah organization, some written documents are found. Oral data are obtained from the people affiliated to the madrasah such as teachers, students, and alumni to complement the research. A 6-year education conducted in a boarding school system builds a long-lasting bond among school managers, teachers, students, and alumni. The alumni agenda that took form in a grand reunion to celebrate the centenary of Madrasah Muallimaat Muhammadiyah in 2018 published a variety of publications to facilitate the author to obtain the oral, written, and visual data of the madrasah.

Analysis of all the collected data is done by the historical method. In historical research, there are several phases that must be completed, namely heuristic data collection, auffasung in the form of verification and criticism of the data to be utilized, and darstellung to measure the data 
prior to composing the report [7]. Therefore, when data are collected, the first important step is to observe the validity of the data by looking at how the historical sources are generated. The data originating from the first source provides a very important role to produce facts. Therefore, data originating from the primary source will be compared with other data, before it is composed into a complete narrative.

Several social sciences researchers have taken into account in regards to the development of education, especially teacher's education. Suwignyo, for instance, detailed that the education of teachers was widely available at the end of the colonial period along with the growing number of elementary educational institutions in Indonesia. In early independence, the condition remained to be dominant, yet only the orientation of the further curriculum has an important push-pull situation, depending on the foundation that oversaw the institutions in question. Muhammadiyah has its own curriculum and patterns in developing education, and significantly different from education developed by the missie and zending, or by the Taman Siswa [8]

In an education system, the curriculum that is compiled and taught in schools will determine the direction of the education itself. The curriculum in the pesantren, the madrasah, and public schools are pointedly different from one another and certainly will generate graduates with a different set of characters. Alumni of pesantren and madrasah are oftentimes had much greater leadership characters than those who graduate from public schools. All collected data, both written, verbal and visual were analyzed using the historical research method to yield historical narrative that can be held accountable within the scientific community [9].

\section{RESULTS AND DISCUSSION}

\section{A. Madrasah Muallimaat as part of the Muhammadiyah Organization}

At the beginning of its founding, the Madrasah Muallimaat has been preserved under the Muhammadiyah organization, and it even becomes the only madrasah by the Muhammadiyah to educate future female teachers and female Muslim leaders.
Indisputably, the slogan inscribed in the front gate of the madrasah is "Mendidik Calon Guru dan PemimpinPutri Islam" (Educating Future Female Teacher and Muslim Leader) as illustrated in Figure 1.

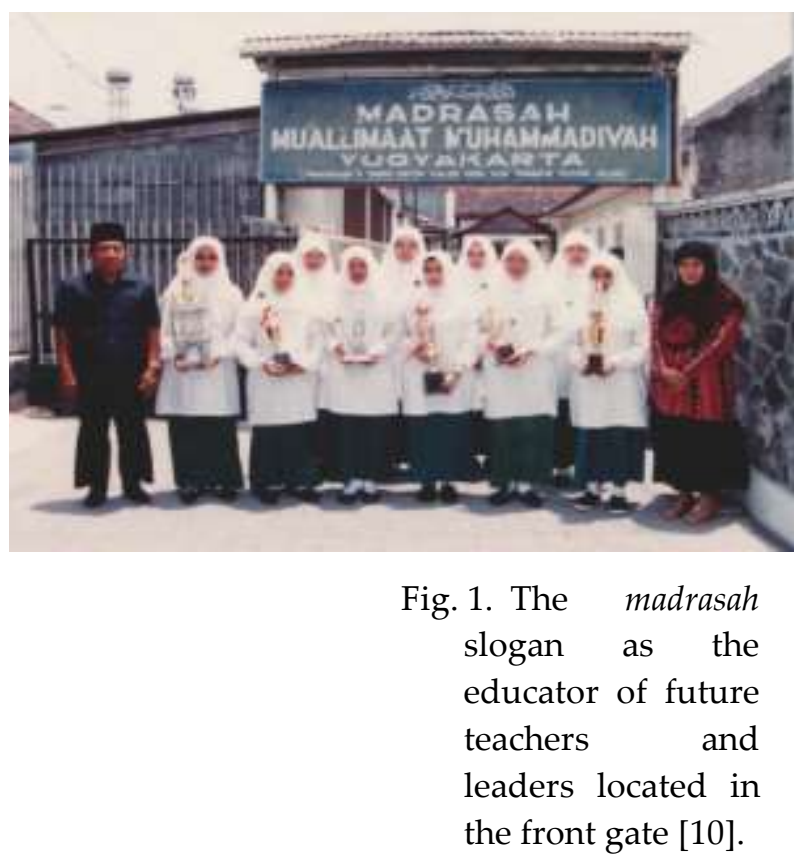

The consequence of this particular slogan, which is to educate future teacher and female Muslim leader, has nurtured the entire curriculum taught at this madrasah to advance towards developing potential teachers and leaders in the society. Apart from that, the Muhammadiyah organization directly administers the madrasah itself and deploys a number of its officials to oversee and direct the staffs at the madrasah towards their main purpose. The structural supervision by the Muhammadiyah can be demonstrated in the institutional structure (Figure 2).

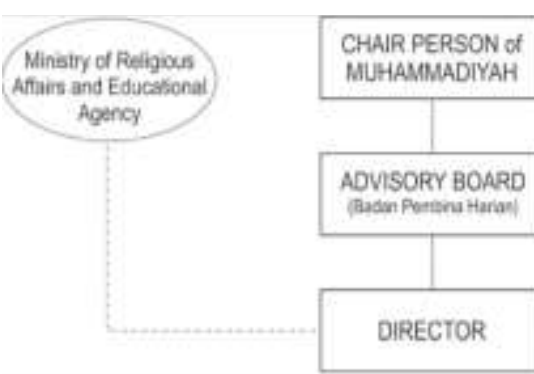

Fig. 2. Structural scheme of Muhammadiyah supervision at the Madrasah Muallimaat Muhammadiyah.

Based from Figure 2, the director of the madrasah is directly under the supervision of the 
Muhammadiyah headquarter through the Badan Pembina Harian, a specific board that routinely deliver aide and guidance to the director in elaborating curriculum at the Madrasah Muallimaat. Aside from that, the director of the Madrasah Muallimaat is indirectly below the Ministry of Religious Affairs (Kementerian Agama) and Educational Agency (DinasPendidikan). It is so due to their independently-developed curriculum that also is aligned with the curriculum that the Ministry of Religious Affairs, thus making it formalized and the graduates are equal to that of those graduating from public schools. This resulted in the alumni to be able to use their diploma to obtain jobs or to pursue higher education, both in public or private universities.

\section{B. The Development of Curriculum}

The system that the Madrasah MuallimaatMuhammadiyah has developed is initially designed as an integrated curriculum, which is to combine a western-style educational system, teacher's education system, with the pesantren system. Since its establishment in 1923 until today, the level of education and curriculum has been regularly renewed. Originally, the madrasah applied 4-year education. However, in 1941, they prolonged the education to 6-year program, dividing it into three years of middle school (Tsanawiyah) and followed by another three years of upper middle school (Aliyah) [4].

In addition, Madrasah Muallimaat Muham madiyah also has a very distinct curriculum created since it was founded. Initially, this madrasah combined the modern education curriculum with pesantren, with a ratio of 60:40. Sixty percent was assigned for general education as an effort to stimulate the competitiveness of the alumni of the madrasah for the future workforce. Forty percent was conducted as a pesantren to strengthen their religious knowledge. The curriculum underwent a stronger substance, at least since 1964 when the curriculum at the madrasah was partitioned into 3 units of competence, namely basic competence, extensiveness of basic competency, and leadership competency. Basic competency comprised areas that included, the knowledge of the AlQuran (the ability to recite AlQuran, memorize Juz'Amma, Tahajud and translation), Hadith, and way of life. In addition, the extensiveness of basic competence consisted of knowledge and language skills, both formal knowledge in languages such as Indonesian, English, and Arabic. The field of leadership is the knowledge of Tauhid, morality, core values of the Muhammadiyah, and teaching education. As prospective Muslim leaders, the formation of upright personality, organizational and administrative knowledge as well teaching become important parts in the construction of the curriculum.

In the 1960s, when the very first curriculum was being taught, the lessons at the Madrasah Muallimaat consisted of both religious and general modules. Those that were included in the religious modules were tawhid, hadith, musthalaah hadith, and fiqh/ushul. For the general modules, they comprised of teaching education that was once not included. Those lessons were teaching and education sciences, general psychology and pediatric psychology. These lessons were essentials given the fact that they were intended to be future educators and female Muslim leaders. A list of lessons taught in the 1960s for the 6-year program as illustrated in table 1.

Table 1. Tahught Subject for Religious and General Modules in the 1960s [11]

\begin{tabular}{llll}
\hline & \multicolumn{1}{c}{ Subjects } & \multicolumn{1}{c}{ Hours of lesson } \\
\hline \multirow{2}{*}{ Religion } & Tawhid & & 9 \\
\cline { 2 - 4 } & & Memorization & 4 \\
\cline { 3 - 4 } & \multirow{3}{*}{ Al Quran } & Recitation & 3 \\
\cline { 3 - 4 } & & Elocution (tajwid) & 1 \\
\cline { 3 - 4 } & & Translation & 8 \\
\cline { 3 - 4 } & & Interpretation (tafsir) & $5 / 2$ \\
\hline
\end{tabular}




\begin{tabular}{|c|c|c|c|}
\hline & \multicolumn{2}{|l|}{ Hadith } & 8 \\
\hline & \multicolumn{2}{|l|}{ Musthalaah hadith } & 3 \\
\hline & \multicolumn{2}{|l|}{ Fiqh/Ushul (jurisprudence) } & $12 / 4$ \\
\hline \multirow[t]{33}{*}{ General } & \multirow{4}{*}{ Teaching science } & Teaching science & 4 \\
\hline & & Education science & 3 \\
\hline & & General psychology & 2 \\
\hline & & Pediatric psychology & 1 \\
\hline & \multirow{5}{*}{ Arabic } & Muthala'ah & 14 \\
\hline & & Imlak & 4 \\
\hline & & Nahwu/Sharaf & 12 \\
\hline & & Muhadatsah & 2 \\
\hline & & Balaghah & 4 \\
\hline & \multicolumn{2}{|l|}{ Khat/Roman alphabet writing } & $3 / 3$ \\
\hline & \multicolumn{2}{|l|}{ Indonesian } & 21 \\
\hline & \multicolumn{2}{|l|}{ English } & 22 \\
\hline & \multirow{3}{*}{ History } & Indonesia/General & 10 \\
\hline & & History (tarikh) & 4 \\
\hline & & Islamic art and culture & 2 \\
\hline & \multirow{4}{*}{ Geography } & Maps & 6 \\
\hline & & Astronomy & 3 \\
\hline & & Natural science & 3 \\
\hline & & Economics & 2 \\
\hline & \multicolumn{2}{|l|}{ Counting } & 5 \\
\hline & \multicolumn{2}{|l|}{ Trading knowledge } & $2 / 2$ \\
\hline & \multicolumn{2}{|l|}{ Algebra } & 11 \\
\hline & \multicolumn{2}{|l|}{ Measurement science } & 8 \\
\hline & \multicolumn{2}{|l|}{ Chemistry } & 9 \\
\hline & \multicolumn{2}{|l|}{ Biology } & 8 \\
\hline & \multicolumn{2}{|l|}{ Law } & 2 \\
\hline & \multicolumn{2}{|l|}{ Economics } & 2 \\
\hline & \multicolumn{2}{|l|}{ Ethnology/Sociology } & 2 \\
\hline & \multicolumn{2}{|l|}{ Vocal art } & 5 \\
\hline & \multicolumn{2}{|l|}{ Drawing/crafting } & 4 \\
\hline & \multicolumn{2}{|l|}{ Physical education } & 12 \\
\hline & \multicolumn{2}{|l|}{ Muhammadiyah core values } & 1 \\
\hline & \multicolumn{2}{|l|}{ Girlscout } & 4 \\
\hline
\end{tabular}

Source: PedomanRencanaPelajaranMu'allimin/Mu'allimaatMuhammadiyahdalamGarisBesar, 1964, pp. 1-4 in[4].

As demonstrated from the Table 1, aside from religious and general modules that they had to study, there were additional lessons which were meant to equip them to become an educator such as teaching and education modules, general psychology and pediatric psychology, oftentimes endured in long hours.
Additionally, the expectation to build leadership and Muhammadiyah values were facilitated through girl scout activity as part of the basic knowledge of Muhammadiyah's prospective cadres. Whereas, further lessons taught at Madrasah Muallimaat were keenly detailed, as illustrated in table 2 .

Table 2. Subject in Madrasah Muallimaat Muhammadiyah [4], [10]

\begin{tabular}{|c|c|c|}
\hline No. & Subjects & Material/Books/Components of Subject \\
\hline 1. & Al Quran & a. Hal Juz'Amma \\
\hline
\end{tabular}




\begin{tabular}{|c|c|c|}
\hline & & $\begin{array}{l}\text { b. Al Quran translation ( } 30 \text { juz) } \\
\text { c. Ayat al-Ahkam } \\
\text { d. Interpretation (tafsir) }\end{array}$ \\
\hline 2. & Hadith & $\begin{array}{l}\text { a. The book of Adabunnabawiyah } \\
\text { b. The book of Hadith Arbai'n } \\
\text { c. The book of Lubanatul Qori } \\
\text { d. The book of Hadith Zabidi }\end{array}$ \\
\hline 3. & Tawhid & $\begin{array}{l}\text { a. The book of Majlis Tarjih (Arkanul Iman with dalil-dalil } \\
\text { naqliya) for grades I-IV } \\
\text { b. b. The book of Risalattauhid Husnulhamidiyyah for } \\
\text { grades V-VI }\end{array}$ \\
\hline 4. & Fiqh & $\begin{array}{l}\text { The book of Majlis Tarjih thaharah, daily prayer, jenazah, } \\
\text { congregation, Friday prayer, shiam (fasting), zakat (charity), } \\
\text { pilgrimage; basic jurisprudence (fiqh) }\end{array}$ \\
\hline 5. & Moral virtue (akhlaq) & Ethics and etiquette \\
\hline 6. & Tarikh (history) & $\begin{array}{l}\text { a. The Jahiliyah (age of ignorance) until the Rashidun } \\
\text { caliphate } \\
\text { b. The Umayyads, Abbasids, and Andalusia } \\
\text { c. Egypt and Crusade } \\
\text { d. Turkish Ottoman and the infiltration of Islam to the } \\
\text { eastern continent } \\
\text { e. The beginning of Islam in Indonesia until the 19th-century } \\
\text { f. The summary of the Prophet's struggle }\end{array}$ \\
\hline 7. & Muhammadiyah values & $\begin{array}{l}\text { a. Organization/administration } \\
\text { b. Muhammadiyah character: capable of leading and } \\
\text { applying the core values of Muhammadiyah organization }\end{array}$ \\
\hline 8. & Arabic & $\begin{array}{l}\text { a. Mukhawaroh } \\
\text { b. Nahwu/sharaf: nahwul-wadlih, safanatunnuhat } \\
\text { c. Mutholaah: al qirotul rasyidah 1-4 } \\
\text { d. Memorization: optional (al muntachobaat) }\end{array}$ \\
\hline 9. & Way of life & $\begin{array}{ll}\text { c. } & \text { Household knowledge } \\
\text { a. } & \text { Production } \\
\text { b. } & \text { Craft } \\
\text { c. } & \text { Trading } \\
\text { d. } & \text { Household domestic affair } \\
\text { e. } & \text { Midwifery } \\
\text { f. } & \text { Femininity } \\
\end{array}$ \\
\hline 10. & Activity & $\begin{array}{l}\text { a. Physical education } \\
\text { b. Scouting (depending on the school and the number of } \\
\text { students) } \\
\text { c. crafting, cooking, and sewing }\end{array}$ \\
\hline 11. & General knowledge & $\begin{array}{l}\text { Such as Indonesian, English, history or any equivalent skills } \\
\text { to the advanced school curriculum. }\end{array}$ \\
\hline
\end{tabular}

Source: Pedoman Rencana Pelajaran Mu'allimin /Mu'allimaat Muhammadiyah dalam Garis Besar, 1964, pp. 1-4 in [4].

As illustrated in Table 2, lessons on way of life became the most vital. The modules were divided into household-related material such as how to make a product, crafting, trading, household affairs knowledge, midwifery and femininity.
Apart from those, leaderships were manufactured through Muhammadiyah segment. The long-existing curriculum which dates back to 1970s is certainly the cornerstone of today's curriculum. This is because some of the current 
curricula are part of the old curriculum which is elaborated in Table 3. adjusted to today's demand, as specifically

Table 2. Madrasah Muallimaat Muhammadiyah 2018 Curriculum

\begin{tabular}{llll}
\hline \multicolumn{1}{c}{ General Subjects } & Religious Subjects & $\begin{array}{l}\text { Language } \\
\text { Proficiency }\end{array}$ & \multicolumn{1}{c}{ Character Building } \\
\hline Biology & Moral (akhlak) & Arabic & Counseling and guidance \\
Economics & Aqidah & Indonesia & Muhammadiyah value \\
Physics & Fiqh & English & $\begin{array}{l}\text { Pancasila and Civic Education } \\
\text { Physical education }\end{array}$ \\
Geography & Hadith & & $\begin{array}{l}\text { Handicraft and entrepreneurship } \\
\text { Chemistry }\end{array}$ \\
Mathematics & Astronomy & & Art and culture \\
Indonesian History & Hadith studies & & Information and \\
& Theology & & technology/handicraft and \\
& & & \\
& & & \\
Sociology & Tafsir & & \\
& Qiro'atul Kutub & & \\
& History of Islamic & & \\
& culture & & \\
& &
\end{tabular}

The current curriculum has transformed as shown inTable 3 . Several previous curricula taught at the madrasah would later be developed into dormitory activity. That is one of the means to accommodate the entire modules that cannot be inserted in a portion of hours of school C. Between Theory-Practice and Dormitory System

The entire modules that are scheduled as the prescribed in the curriculum are channeled through theory and practice. In this case, the most essential would the actualization of the theory taught at school and applied within the confinement of the dormitory as well as the society. The practical subjects allow an additional value to practicality such as worship, femininity, and leadership. The worship modules are manifested into the practice of shalah (daily prayer), $\mathrm{Al}$ Quran recitation and other applications. Whereas, the femininity core values can be seen through the activities of cooking in a group. The same idea applies to leadership modules through extracurricular activities. That way, the ability of the student to assume the position of a leader becomes the emphasis in every activity.

Aside from the main modules in the classroom, the Madrasah Muallimaat also teaches its students the ability of leadership that is prepared in a variety of forms. In the elementary subjects as required by the Ministry of Religious Affairs. Henceforth, the solution is to shift the subjects to dormitory activity and manifesting them into extracurricular activities to shape potential teachers and expected female Muslim leaders.

level shortly after their admission, they hold an orientation program. Its aim is to introduce them to the school environment better, as they stand in front of the front gate which allows them to see the school slogan and leadership posters installed in every corner of the premise. Thus, leadership preparation is expected from the very beginning. Moreover, there is also a program called DarulArqam or an elementary leadership program in a series of workshops. In the practical aspect, the activity of MubalighHijrah allows the student to prepare them to directly receive the ability in leadership. They are expected to live independently within a community that they have no prior knowledge before. Afterward, they teach religious guidance to local people. DarulArqam is a month-long program that is normally practiced during the Ramadan. Those with the least knowledge of leadership can join the leader to enrich their understanding of leadership [5].

The entire curriculum that is applied in school may not succeed effectively if it is not 
integrated at home. Hence, the boarding-school system as part of their program. For all students, the majority of them are the future Muhammadiyah cadres in every branch of Muhammadiyah in Indonesia by allowing them to lodge in a boarding house. The compound is well-kept accompanied by excellent management. Each house has a perfect to assume the role of parents while they live inside the premise as well as providing tutors. A tutor leads a collective, which consists of 10 students. They are guided throughout all activities within the boarding house such as in terms of daily activity, religious worship to studying.

\section{How to Operate Ideas Institutionally?}

Educating students to be prepared for female Islamic leadership has become the sole curricula that had to be maintained through generations within the Madrasah Muallimaat Muhammadiyah. This is proven to be crucial since its implementation in 1932 until today.

A leap of consciousness has been indicated by the founders of Madrasah Muallimaat Muhammadiyah upon establishing the institution that is still preserved today. This consciousness that bearing female Islamic leaders became the necessity for the nation in the present day and the future. Muhammadiyah maintains the consistency of ideas in a structural manner. It is not only exhibited in its leadership structure and its implemented supervision, but also through its daily operation. Within the structure, direct supervision is assumed by the advisoryboard (as suggested in Fig. 2). Subsequently, the madrasah leadership evaluates and implements the existing curriculum periodically and regularly. Beyond the structure, alumni and parents of the students inclusively oversee until their aspiration in forging the future "female Islamic leader" can be achieved.

\section{CONCLUSIONS}

The consistency in the educational system at the Madrasah MuallimaatMuhammadiyah is one of the vital strength to maintain the institution to endure until the present-day. With the consistency, the Madrasah Muallimaat is sufficiently competent to prepare their alumni to compete in society and make them prospective female Muslim leaders like the slogan that the madrasah espouses. Therefore, consistency in the system is significantly important that has managed to deliver this madrasah amidst this globalized competitive platform.

\section{ACKNOWLEDGMENTS}

The writers thank those who involved in writing this article.

\section{REFERENCES}

[1] A. Azra. (2014). Jaringan Ulama Timur Tengah dan Kepulauan Nusantara Abad XVII $\mathcal{E}$ XVIII: Akar Pembaruan Islam Indonesia. Jakarta: Prenada Media Group.

[2] M. Fuad. (2002). Civil Society in Indonesia: The Potential and Limits of Muhammadiyah.Sojourn J. Soc. Issues Southeast Asia, 17(2), pp. 133-163.

[3] Taroena. (1992). Tjalon Kweekschool Islam.Soewara Moehammadijah, Djogjakarta.

[4] S. Mustaani. (2002). Madrasah Mu'allimaat Yogyakarta 1932-1973. Universitas Gadjah Mada.

[5] R. Hayati. (2018). Evaluasi Proses Pelaksanaan Pendidikan Kepemimpinan di Madrasah $\mathrm{Mu}^{\prime}$ allimaat Muhammadiyah Yogyakarta. Universitas Muhammadiyah Yogyakarta.

[6] Kuntowijoyo. (2003).Metodologi Sejarah, 2nd ed. Yogyakarta: Tiara Wacana.

[7] S. Grigg. (1991). Archival Practice and the Foundations of Historical Method.J. Am. Hist., vol. 78(1), pp. 228.

[8] A. Suwignyo. (2012). The Breach in the Dike: Regime Change and the Standardization of Public Primary-school Teacher Training in Indonesia, 1893-1969. Leiden University.

[9] G. J. Renier. (2018).History: Its Purpose and Method, 1st ed. Abingdon: Routledge.

[10] Sejarah Madrasah Mu'allimaat Muhammadiyah Yogyakarta. (2018). Retrieved from http://www.muallimaat .sch.id/profil-9. [Accessed: 18-Dec-2018].

[11] M. Junus. (1960).Sedjarah Pendidikan Islam di Indonesia. Djakarta: Pustaka Mahmudiah 